\title{
Universiteit
}

Leiden

The Netherlands

\section{Explaining crime and gender in Europe between 1600 and 1900}

Heijden, M.P.C. van der; Pluskota, M.; Muurling, S.T.D.

\section{Citation}

Heijden, M. P. C. van der. (2020). Explaining crime and gender in Europe between 1600 and 1900. In M. Pluskota \& S. T. D. Muurling (Eds.), Women's criminality in Europe, 1600-1914 (pp. 26-45). Cambridge: Cambridge University Press. doi:10.1017/9781108774543.002

Version: $\quad$ Publisher's Version

License: $\quad$ Licensed under Article 25fa Copyright Act/Law (Amendment Taverne)

Downloaded from: $\quad$ https://hdl.handle.net/1887/3238714

Note: To cite this publication please use the final published version (if applicable). 


\title{
2 Explaining Crime and Gender in Europe between 1600 and 1900
}

\author{
Manon van der Heijden
}

\section{Introduction ${ }^{1}$}

European crime and criminal justice statistics show that women are responsible for a much smaller proportion of indictable offences than men: approximately 13 per cent of all prosecutions in Europe. ${ }^{2} \mathrm{Next}$ to biological differences between men and women, this strong gender difference in criminal behaviour is often linked to differences in the public lives of men and women. The fact that women have lesser freedom and fewer opportunities may cause a lower participation by women in crime and may also lead to more lenient treatment by prosecutors. ${ }^{3}$ Furthermore, scholars generally assume that such sex differences in recorded crime rates are consistent, stressing the continuity of men's excessive contribution to criminality. ${ }^{4}$ Consequently, most scholars working on crime consider female criminality less important and focus their attention on explaining men's criminality rather than looking at both men and women. This chapter stresses the importance of discontinuity and variation in female crime and aims to contribute to the understanding of crime and gender by looking at various factors that may have determined women's crimes between 1600 and 1900 in Europe. There are two important reasons for emphasising the importance of variation in female crime: (1) there is a misconception about continuity in the proportion of female crime and (2) women are underrepresented in historical studies on crime.

1 This chapter is based on the research proposal Crime and Gender 1600-1900: A Comparative Perspective, which received an NWO VICI grant in 2012 (www.crimeandgender.nl).

2 European sourcebook of Crime and Criminal fustice Statistics 2014.

3 Adler, Sisters in Crime: Pollak, The Criminality of Women; Arnot and Usborne, Gender and Crime; Silvestry and Crowther-Dowey, Gender E Crime, 9. Burkhead, The Search for the Causes of Crime.

4 Heidensohn, Crime and Society; Burkhead, The Search for the Causes, 50; Silvestry and Crowther-Dowey, Gender E Crime, 26, 191. 
Since the 1900s criminal statistics on Europe demonstrate women's small contribution to crime, but it would be wrong to conclude that women's roles in crime are always and everywhere insignificant. Data on early modern Europe show that in France, England, Scotland, Germany and the Netherlands between 1600 and 1900 women played a much more prominent role in crime than in the twentieth century. ${ }^{5}$ Such data reveal that women's involvement was not limited to 'traditional' female offences, such as infanticide, witchcraft and prostitution. Women also constituted a large part of the cases that are typically associated with male crime, such as property offences and sometimes violence. ${ }^{6}$ There are clear indications that in Western Europe between 1600 and 190020 to 50 per cent of the property crimes (theft and burglary) were committed by women. ${ }^{7}$ In contrast, in the twentieth century, women were in general responsible for only 12 per cent of the property crimes. ${ }^{8}$ Such findings indicate that women's participation in crime varied over time and space.

The high percentages of female crime in the seventeenth and eighteenth centuries have led to an academic debate about trends in male and female recorded crime. Using data from several European cities, the criminologist Feeley argues that - as a result of increasing patriarchal structures - the female percentage in crime declined dramatically during the eighteenth century. ${ }^{9}$ Other scholars have raised substantial doubts about the idea of the 'vanishing female'. ${ }^{10}$ King maintained that the English evidence points to long-term stability in female recorded crime in the eighteenth and nineteenth centuries rather than to a longterm decline. ${ }^{11}$ Looking at various Dutch cities in the eighteenth century

5 Farge, Délinguance et criminalité; Feeley and Little, 'The Vanishing Female'; Feeley, 'The Decline of Women in the Criminal Process'; van der Heijden, 'Criminaliteit en sekse in 18e-eeuws Rotterdam'; King, Crime and the Law; Kilday, Women and violent crime; Spierenburg, A History of Murder, 117.

6 Beattie, Crime and the Courts; Schwerhoff, Köhln im Kreuzverhör; Feeley, 'The Decline of Women in the Criminal Process'; van der Heijden, 'Criminaliteit en sekse in 18e-eeuws Rotterdam'; King, Crime and the Law; Zedner, Women, Crime and Custody.

7 Schwerhoff, Köhln im Kreuzverhör, 178; Feeley, 'The Decline of Women in the Criminal Process', 235; Wunder, 'Weibliche Kriminalität in der Frühen Neuzeit'; Eibach, 'Städtische Gewaltkriminalität im Ancien Régime'; Wettmann-Jungblut, 'Modern times, Modern Crimes?'; van der Heijden, Women and Crime.

8 European Sourcebook of Crime and Criminal Fustice Statistics 2003, 64-5 and 2006, 67-6.

9 Feeley and Little, 'The Vanishing Female'; Feeley, 'The Decline of Women in the Criminal Process'.

10 Emsley, Crime and Society, 152; Arnot and Usborne, Gender and Crime, 8; King, Crime and the Law; van der Heijden, Women and Crime, 13-17.

11 King, Crime and the Law, 220. 
and statistical data on the Netherlands in the nineteenth century, van der Heijden and Koningsberger have come to similar conclusions. Detailed investigation of Dutch sources has revealed that there was long-term continuity in the relatively high female share in prosecutions and convictions between 1750 and $1838 .{ }^{12}$ Recent examinations of female crime in Europe indicate that the proportion of women in crime began to decline decades later, presumably in the second half of the nineteenth century or even later. ${ }^{13}$

The focus on quantitative analyses of crime in the period between 1600 and 1900 has led to a general underrepresentation of women's crimes in historical studies. As social historian Walker stated in 2003: 'What tends to happen is that women are counted, and as being a minority of offenders, are subsequently discounted as unimportant'. ${ }^{14}$ German historian Schwerhoff made similar remarks with regard to the pitfalls of focusing the study of crime on counting and gathering quantitative data. ${ }^{15} \mathrm{~A}$ qualitative approach may give a much more nuanced picture of women and crime and may give a better insight in the social, economic and cultural circumstances that led to criminal behaviour. Various studies on women and crime in early modern Europe emphasise the similarities in male and female crime, indicating that generally men and women committed similar types of crime (such as theft and minor violence).${ }^{16}$ More consistent and comparative evidence is needed to understand changes in women's crime throughout the period. Even more importantly, it is crucial to combine both quantitative and qualitative approaches for a proper understanding of female crime proportions.

This chapter aims to define the most important determinants of women's crimes between 1600 and 1900 in Western Europe. I will first briefly summarise the debate on public roles in relation to differences in the criminal behaviour of men and women. I will then look at the various factors that can explain the variations in women's criminality as well as variation in the prosecution of crime: (1) moral and legal norms, (2) urbanisation, (3) household system, (4) labour participation and (5) living standards. By comparing findings from different

12 Van der Heijden and Koningsberger, 'Continuity or Change?', 101-27.

13 Pluskota, 'Petty Criminality, Gender Bias and Judicial Practice in 19th-century Europe', Fournal of Social History 51 (2018), 723.

14 Walker, Crime, Gender and Social Order, 4. For a Dutch account on the matter of counting female crime: Schmidt and Pluskota, 'Gevaarlijke vrouwen, misdadige mannen?'

15 Gerd Schwerhoff, Aktenkundig und Gerichtsnotorisch, 149-66.

16 Trevor Dean, 'Theft and Gender in Late Medieval Bologna', 399-415; Walker, Crime, Gender and Social Order; van der Heijden, Women and Crime. 
regions in Western Europe, such as England, Germany, Italy and the Netherlands, this chapter aims to assess the impact of such on the prosecution of female crime between 1600 and 1900.

\section{Notions of Public Roles and Gender Differences in Crime}

Crime historians generally relate gender differences in recorded crime to ideologies and practices of male and female public roles. Characteristic aspects of male and female roles in social, cultural and economic systems can all be related to a universal structural opposition between the domestic and public domain of activity. ${ }^{17}$ Generally, there are two sets of explanations for the gendered pattern of prosecuted crime: (1) Women actually commit fewer and different crimes than men because of the different nature of their lives: women are more confined to the domestic sphere, while men have more freedom to engage in public and criminal activity. (2) According to their prescribed gender role, women are expected to be less criminal and more law-abiding, resulting in biased criminal justice procedures. ${ }^{18}$ Historians who use the concept of public roles focus on the nineteenth century, assuming that the separation of public and private spheres caused gendered crime patterns. ${ }^{19}$ Although the distinction between private and public spheres has been seen as particularly appropriate to the late eighteenth and early nineteenth centuries when the ideology of separate spheres intensified, scholars who focus on the early modern period have also adopted this terminology. ${ }^{20}$

There is an important problem with the concept of separate private and public spheres: it masks the fact that both men and women moved easily from so-called private to public spheres. ${ }^{21}$ Shoemaker rightly argued that historians should make clearer distinctions between moral

17 Shoemaker, Gender in English Society, 305.

18 Shoemaker, Gender in English Society; Zedner, Women, Crime, and Custody; Schwerhoff, Köhln im Kreuzverhör; Rublack, The Crimes of Women; Palk, Deirdre, Gender, Crime and Fudicial Discretion; King, Crime and the Law; Spierenburg, $A$ History of Murder.

19 Feeley and Little, 'The Vanishing Female'; Feeley, 'The Decline of Women in the Criminal Process'; Zedner, Women, Crime and Custody; Palk, Gender, Crime and Fudicial Discretion; Emsley, 'Review of Deirdre Palk'.

20 Shoemaker, Gender in English Society (1988 and 1991); Arnot And Usborne, Gender and Crime, 23-4; Rublack, Gender in Early Modern German History.

21 Shoemaker, Gender in English Society, 311; Kermode and Walker, Women, Crime and the Courts; Arnot and Usborne, Gender and Crime, 23; Eibach, Frankfurter Verhöre; Menchi and Quaglioni, I tribunali del matrimonio; Vickery, 'Golden Age to Separate Spheres?', 413. 
norms about the public roles of men and women and their actual roles in everyday lives. Dominant household ideologies may have emphasised the domestic and passive character of women, but in practice women transcended the realm of the household, engaging in many activities. ${ }^{22}$ The gendered patterns in recorded crime depend as much on moral and legal norms relating to the different public roles of men and women as on their actual roles in everyday life. The various religious and legal forces promoting gender differences were not always successful, and there were many instances where in practice women engaged in activities in markets, workplaces, streets, places of recreation or around community buildings and facilities. ${ }^{23}$

A second fundamental problem has been raised by Eibach in his work on early modern households. He suggests that the separation between public and private spheres might be irrelevant for the early modern period because of the blurry notions of private and public. A strict division between public and private activities omits the large overlap within the private and public lives of men and women. Urban authorities, such as magistrates and churches, did not distinguish between public and private activities, and they attempted to control behaviour occurring in the streets as well as in people's homes. ${ }^{24}$ The private-public dichotomy is particularly problematic for the study of crime, because crimes were committed in a wide variety of places and not all of them easily labelled as private or public. ${ }^{25}$ Men and women committed violence and sexual crimes in the house or around the household out of the sight of others, though involving contact with non-family or non-household members. There are many examples of female domestic servants who were accused of stealing goods from the houses of their employers or unwed mothers who killed their illegitimate new-borns nearby their homes out of fear and desperation. Adultery and fornication were often committed in the realm of private or secluded places, though considered a crime that had to be dealt with publicly by secular or ecclesiastical authorities. The idea of gendered public and private spheres is therefore a helpful notion but too limited for explaining men's and women's criminal behaviour and their proportion in crime.

22 Eibach, 'Der Kampf um die Hose', 167-88; Eibach, 'Das offene Haus', 621-55.

23 Shoemaker, Gender in English Society, 313; Wunder, 'He Is the Sun, She Is the Moon'; Rublack, The Crimes of Women; Jacobson Schutte, Kuehn and Seidel Menchi (eds.), Time, Space and Women's Lives; Wright, 'Female Crime and State Punishment'; Walker, Crime, gender and social order; van der Heijden, Women and Crime.

24 Eibach, 'Das offene Haus'.

25 Sanne Muurling and Marion Pluskota, 'The Gendered Geography of Violence in Bologna'. 
When looking at public and private roles, it might be useful to include the concept of 'agency' and the variety of active roles of men and women in analysing their crimes. Although historians agree that social-cultural structures and economic circumstances cause gender differences in crime, no systematic analysis has been carried out to explain which factors are conducive to the leeway of men and women to lead public lives and to commit crimes. The activities of men and women and the incentive to commit crime is strongly determined by circumstances that have varied over time and space. In the next paragraphs, I will discuss the factors that can explain the varying criminal activities of men and women and their share in prosecuted crimes.

\section{Moral and Legal Norms of Public Roles}

Gender differences in recorded crime are first of all linked to value systems that have varied over time and space. Moral and legal norms about the behaviour of men and women affected their roles in everyday lives, their daily activities and their opportunity to commit crimes. In this respect, there were important differences for men and women between the regions in northern and southern Europe. Seventeenthcentury travellers from England, Germany and Holland to Italian cities often remarked on the less visible lives of the women in these cities and related this to the importance of honour and female virtue. ${ }^{26}$ Such distinctions between the north and the south are heavily debated and do not account for significant differences between the image of women and their actual lives in cities. We will come back to this matter in the paragraph on household system.

Moral and legal norms also led to biased prosecution policies, particularly relating to sexual behaviour and religious matters. In the sixteenth and seventeenth centuries, authorities in both Protestant and Catholic countries of the Counter-reformation increased their control over sexual behaviour and religious attitudes. ${ }^{27}$ Scholars generally refer to sexual and religious offences as 'soft crimes', because the definition and prosecution of such infringements depend on continuously changing moral norms. The trends in 'hard crimes' - such as homicide, violence and theft - are easier to disclose, though so far such examinations seldom include gender differences. ${ }^{28}$

\footnotetext{
26 Viazzo, 'What's So Special About the Mediterranean?', 117.

27 Cohn, Women in the Streets, 57.

28 Dean, 'Theft and Gender', 399.
} 
Although men were accused of sexual and religious offences as well, women were more likely to be arrested and treated less leniently by the judges. ${ }^{29}$ These double standards explain - at least in part - why female crime shares were sometimes exceptionally high in the early modern period. During episodes of large-scale witch-hunts, female crime shares rose considerably in the German areas. ${ }^{30}$ Double standards of prosecutors regarding the sexual behaviour of men and women could also lead to high female crime shares. In most European towns, women were more likely to be arrested for fornication, adultery and prostitution, and they generally received harsher treatment for their sexual crimes than men, particularly if they had committed such crimes in public spaces. For example, in early modern Holland, the law prescribed a more serious punishment of female adulterers than of their male counterparts. ${ }^{31}$

Prosecutors applied double standards with regard to male behaviour as well. High levels of wife-killing in late medieval Bologna - in comparison with cities in northwest Europe - may be explained by a general expectation that husbands would use violence against their wives. ${ }^{32}$ Such value systems would change over time. Wiener found that in England disproportional male violent behaviour was increasingly prosecuted in the course of the eighteenth and nineteenth centuries. ${ }^{33}$ New ideas about family values, domestic violence and the protection of children would have led to an increasing focus on violence committed by men. Although some historians assumed that the British case represented a general western European pattern, recent examinations on Holland suggest that the increasing focus on the prosecution of male violence may have been a particular British phenomenon. The common law in England gave the court more freedom to differentiate their sentences according to gender, while on the Continent, courts were usually bound by the Penal Code and consequently violent women were not treated with more leniency than men. ${ }^{34}$

The judicial system played an important role in the prosecution of male and female crime. Different types of courts - lower and higher,

29 Schwerhoff, 'Geslechtsspezifische Kriminalität im früneuzeitlichen Köln', 91; van der Heijden, 'Criminaliteit en sekse in 18e-eeuws Rotterdam', 16.

30 Schwerhoff, Köhln im Kreuzverhör; Schwerhoff, 'Geslechtsspezifische Kriminalität im früneuzeitlichen Köln'; Behringer, 'Weather, Hunger, Fear'; Levack, The Witchhunt; Durrant, Witchcaft, Gender, and Society.

31 Heijden, Huwelijk in Holland, 114-16.

32 Van der Heijden, 'Women as Victims', 633; Dean, 'Domestic Violence', 532.

33 Wiener, 'The Victorian Criminalization of Men', Spierenburg, A History of Murder; Muchembled, $A$ History of Violence.

34 Heijden and Pluskota, 'Leniency or Toughening?'; Brown and Davis, Gender and Society, 21-3; Dean, 'Theft and Gender', 400; Cohn, Women in the Streets, 35-7. 
local and central, secular and ecclesiastical - handled different types of crime and employed different kinds of procedures. Women's crimes were more likely to be handled by lower courts or less informal methods of dispute regulation than by higher courts. ${ }^{35}$ King stresses that jurisdictional changes in London account for much of the reduction in the appearance of women at the Old Bailey after 1850, as women seem to have been excluded from the state-initiated parts of the criminal justice system. ${ }^{36}$ On the Continent, in France, Germany, Italy and the Netherlands, bureaucratisation and centralisation caused a fundamental reform of the judicial system as well. ${ }^{37}$ The rise of a professional judicial system had an effect on the different outcomes of recorded male and female crimes in different areas and different periods of time. Such changes explain different prosecution policies (towards men and women) in various countries in Europe. Whereas England, Italy and the Netherlands were characterised by a decentralised process of state formation, Lucassen found that in Germany the concept of policing and exclusion was much broader, making certain groups more vulnerable to criminalisation than in others parts of Europe. ${ }^{38}$

The moral and legal norms not only shaped prosecution policies, but also the uses of justice by (urban) populations, which can help explain the different outcomes of recorded male and female crimes in different areas and different periods of time. German historian Dinges has argued that in the early modern period people used the judicial institutions as an instrument of everyday social control, and historians should therefore focus on the ways and the extent that people had recourse to justice in order to explain patterns of prosecution. ${ }^{39}$ The comparison of various forms of justice in early modern Holland reveals that women's complaints as well as their crimes become more apparent in the records of lower and more accessible criminal courts. ${ }^{40}$ The prosecution of men's and women's crimes by the early modern courts were thus as much the outcome of bottom-up social control mechanisms as of top-down social control exercised by authorities.

35 Gray, Crime, Prosecution and Social Relations, 9, 170-1; Schwerhoff, Köhln im Kreuzverhör; Shoemaker: 1998, 292; Williams, 'Counting Crime or Counting People', 77-93; King, Crime and the Law, 202-10.

36 King, Crime and the Law, 210; Williams, 'Counting Crime or Counting People'.

37 Leonards, De ontdekking van het onschuldige criminele kind; Härter: 2008; van der Heijden: 2010.

38 Lucassen, Between Hobbes and Locke, 432-8.

39 Dinges, 'The Uses of Justice', 159-75.

40 Van der Heijden, 'Women, Violence, and Urban Justice'. 


\section{Urbanisation}

A second crucial factor in explaining the levels of male and female crime in relation to their public roles in the early modern period is the degree of urbanisation. In his pioneering work on English crime, Beattie found women's contribution to crime to be generally much higher in cities than in rural communities or small towns. The lack of economic and social support from the traditional community caused women in towns to lead more independent, public and risky lives. ${ }^{41}$ Castan and Farge have drawn similar conclusions on eighteenth-century rural and urban France. ${ }^{42}$ For many young lower-class women migrating from the countryside to the city, criminal activities such as theft, burglary and prostitution became a logical survival strategy..$^{43}$

High urbanisation levels also help to explain differences between male and female crime rates between 1600 and 1900 in various countries in Europe. The relatively low level of urbanisation (and smaller towns) in Germany and France - compared to that of England and the Netherlands - may explain the lesser public role of women and the consequently low female proportion in crime during that period of time. ${ }^{44}$ Around 1700, 30 to 40 per cent of the Dutch population lived in towns, in England 20 per cent, in Italy 18 per cent and in Germany 5.5 per cent. In Holland (the western part of the Netherlands) the level of urbanisation was 70 per cent. ${ }^{45}$ English historians found high levels of female crime in the records of the London area, and recent examinations on women and crime in early modern Holland show that in Dutch cities the share of women in crime was remarkably high (between 30 and 50 per cent of all prosecutions). ${ }^{46}$

Urban decline may have caused a decline in women's share in crime. German historian Schwerhoff found that in the seventeenth century about 17 per cent of those arrested in the German town of Cologne were women. ${ }^{47}$ In the same period, women were responsible for almost 50 per cent of the crimes in Amsterdam and 30 to 50 per cent of the

41 Beattie, 'The Criminality of Women', 81; Beattie, Crime and the Courts; Shoemaker, Prosecution and Punishment, 208-209).

42 Castan, Les criminels de Languedoc; Farge, Délinguance et criminalité, 116; Hufton, The Poor of Eighteenth-Century France, 278-80.

43 Moch, Moving Europeans, 146; Pluskota, Prostitution and Social Control

44 Shoemaker, Gender in English Society, 291.

45 De Vries and Van der Woude, Nederland 1500-1811, 83; Clark, European Cities and Towns, 119-23, 128.

46 Van der Heijden, Women and Crime.

47 Schwerhoff, Köhln im Kreuzverhör, 178; Schwerhoff, 'Geslechtsspezifische Kriminalität im früneuzeitlichen Köln', 87. 
court cases of the London Old Bailey. The fact that 80 per cent of the witnesses in Cologne's criminal cases were men, and that women were seldom accused of offences against the authorities, points to a less visible role of women in the public space. In addition, most female crimes were committed around the house, while most men committed their crimes around the marketplace. ${ }^{48} \mathrm{~A}$ decline in women's less public roles after 1500 resulted in a decline of the percentage of women in crime in the Italian cities as well. Cohn's analysis of the Florentine criminal records demonstrates that women were less able to circulate as freely through the streets of the city as they had been in the fourteenth century. Women's less active public life and a decline in the accessibility of the courts to women would have resulted in a sharp decline of women appearing in the criminal tribunals. ${ }^{49}$ Much more research is required before any conclusion can be reached, but the decline in women's public roles and the declining share of women in crime in Italian cities may in part be explained by long-term urban and economic decline in Italy after 1500 .

In terms of economic growth and the level of urbanisation, balances shifted between northern and southern Europe in the course of the early modern period. In the sixteenth and seventeenth centuries, the populations of northern Italian cities stagnated or declined, while the populations of Dutch and English cities grew rapidly (often referred to as little divergence). Around 1800 London assumed the role of the leading global as well as European metropolis with nearly a million inhabitants. ${ }^{50}$ In the same period Amsterdam had 217,000 inhabitants, Bologna 70,000 and Frankfurt 32,000-39,000.51 The size of a city and the proportion of migrants had an significant impact on the involvement of women in crime. Maritime cities such as London, Amsterdam and Rotterdam were characterised by a surplus of women, a high percentage of households headed by women and relatively large populations of women on their own, most of whom belonged to the lower social strata. Women in these cities lived more independent and public lives, and as a result, they generally ran higher risks of becoming involved with the law than their counterparts in less dynamic towns. ${ }^{52}$

48 Schwerhoff, Köhln im Kreuzverhör, 180, 451. See also Eibach, Frankfurter Verhöre, 247.

49 Cohn, Women in the Streets, 37. See also Dean who warns us against a too simple binary divide between the public roles of men and women in relation to their crimes: 'Theft and Gender', 400.

50 Clark, European Cities and Towns, 113, 123.

51 Hughes, Crime, Disorder and the Risorgimento, 7; de Vries and van der Woude, Nederland 1500-1811; Eibach, Frankurter Verhöre.

52 Van der Heijden, Women and Crime, 17-21; Gray, Crime, Prosecution and Social Relations, 170; Shoemaker, Prosecution and Punishment, 215-16. 


\section{Family Systems}

Family structures offer a third important explanation for the differing scope of men and women to undertake public activities. Economic historians van Zanden and De Moor argue that the relatively independent position of women in pre-industrial Northern Europe - England and the Netherlands in particular - originated from three sets of factors: (1) the Christian ideal and practice of mutual consent in marriage, (2) relatively equal inheritance laws and (3) The importance of wage labour. These factors were conducive to the economic independence of both men and women, offering women greater freedom to make their own choices and to play public roles. ${ }^{53}$ Van Zanden and De Moor link the family system to the degree of agency and autonomy of women to explain differences in economic growth between regions, but the link between family system and women's agency may also be a good indicator for differences in the proportion of women in crime in various regions in Europe. ${ }^{54}$

Using the Emmanuel Todd classification for family systems, demographic historian Kok suggests that the absolute nuclear family which was found in England and the western parts of the Netherlands (Holland) - signified a relative freedom of choice of a marriage partner and relatively equal inheritance laws. ${ }^{55}$ The authoritarian family was found in the German areas and characterised by impartial inheritance, with the male heir co-residing with his parents. In the latter system, marriages were exogamous and frequently arranged by the parents. In addition, family ties were strong; children lived at home until marriage and are supported by their parents for a long period. Within the absolute nuclear system, weak family ties were reflected in a relatively early age of leaving home, a relatively long period of independence before marriage, late marriage and high percentages of singles and one-parent families. ${ }^{56}$ In Italy, strong patriarchal values and strong family disadvantaged women's access to property (inheritance and dowry), and there were statutory restrictions on women's legal agency. ${ }^{57}$

Differences between family systems probably had a significant impact on the freedom of men and women to lead public lives. Although the

53 Van Zanden and De Moor, Vrouwen en de geboorte van het kapitalisme.

54 Carmichael, De Pleijt, Van Zanden and De Moor, 'The European Marriage Pattern and Its Measurement'.

55 Kok, 'The Family Factor in Migration Decisions'.

56 Moch, Moving Europeans, 32.

57 Kuehn, 'Daughters, Mothers, Wives, and Widows', 114-15; Kuehn, 'Gender and law in Milan', 416; Cohn, Women in the Streets; Cohn, 'Women and Work', 1998. 
strength of patriarchal values in Italy has been a subject of debate, scholars generally agree that strong family ties and women's relatively weak legal position restricted their opportunities to participate in public life. ${ }^{58} \mathrm{Da}$ Molin has pointed out that in the south of Italy women between the ages of 15 and 25 - in order to protect their honour and virginity - were not allowed to work outside the home. ${ }^{59}$ In the more urbanised regions of Italy, women were restricted as well; female textile workers usually did their work at home and women were not allowed to freely move around in urban public space. Many city's by-laws required respectable women to be accompanied at night by a male guardian or relative. ${ }^{60}$ In England and Holland, the family system allowed women much more freedom to act and move around independently. In seventeenth and eighteenth century Holland and England, unmarried women, widows and, sometimes, married women were more likely to make independent decisions regarding migration, marriage and work, and they often obtained more legal powers than their counterparts in Germany and Italy. ${ }^{61}$

Reher suggests that it was not only the family system (age of marriage, neo-locality) that made a difference in the strength or weakness of family ties, but also the way in which people left their homes. While young people in the northern regions of Europe became a servant in another household before marriage, in the southern parts youngsters left their parental home as a married person or as a lifelong servant. In the latter case, family members may have had less agency to act independently, but they did receive organised support from their family members in times of need. ${ }^{62}$ The vulnerable and poor young women that turned to crime in the early modern cities of Holland did not receive such support from household members. Not only because many of them were migrants and a long way from home, but also because in Holland domestic servants were not necessarily seen as a member

58 Viazzo, 'What's So Special About the Mediterranean?'

59 Da Molin, 'Family Forms and Domestic Service'; Viazzo, 'What's So Special About the Mediterranean?', 126.

60 Cohen, 'To Pray, to Work, to Hear, to Speak', 303; Muurling and Pluskota, 'The Gendered Geography of Violence in Bologna', 157.

${ }_{61}$ Wiesner, Women and Gender, 94; Rublack, The Crimes of Women, 256; Ogilvie, $A$ Better Living, 9; Schmidt, 'Vrouwenarbeid in de vroegmoderne tijd', 2-21; van der Heijden, van Nederveen Meerkerk and Schmidt, 'Terugkeer van het patriarchaat?'; van der Heijden and Schmidt, 'Public Services and Women's Work'; Cohn, Women in the Streets, 37.

62 Reher, 'Family Ties in Western Europe'. 
of the household. ${ }^{63}$ In a recent study on female crime and household control in Germany, Kamp suggests that strong informal control by household authorities can explain low percentages of female crimes in German towns. She found that in early modern Frankfurt housefathers (Hausväter) protected as well as disciplined all members of the household, including migrant domestic servants. The female offenders that were prosecuted by the urban court were those who had failed to secure a position within a household and to receive protection from the housefather. ${ }^{64}$ The authoritarian family, as described by Todd and Kok, thus affected how female crime was prosecuted in Frankfurt in the seventeenth and eighteenth centuries.

The relatively independent position of women and their consequently larger public roles can explain the exceptionally high proportion of women in recorded crime in the towns of England and Holland. Being involved in public activities, women had more opportunities to make their own decisions, to move around freely and to work outside the home. This freedom also made them more vulnerable and caused greater risks of becoming involved with the law. Because of their more public lifestyles, the insecurity of their employments and the lack of family support, independent women - especially if they were lowerclass - were more likely to enter into disputes and to commit crime in times of hardship. ${ }^{65}$

\section{Labour Participation}

Women's agency and freedom to lead public lives are related to their position on the labour market. Although there is still little comparative data available on labour participation rates of women in early modern Europe, there are indications that the level of women's labour participation was relatively high in Holland and England during the seventeenth century when the levels of women's participation in crime were high as well. ${ }^{66}$ Schmidt suggests that female labour participation was higher during the Dutch Golden Age (1580-1650), because the demand for

63 Van der Heijden and Schmidt, 'Public Services and Women's Work'; van der Heijden and Schmidt, 'Der Haushalt in de niederländischen Geschichtsschreibung', 131-47.

64 Kamp, 'Female Crime and Household Control in Early Modern Frankfurt am Main', 531-50.

65 Shoemaker, Prosecution and Punishment, 208-209; van der Heijden, Women and Crime, 17-23.

66 Schmidt and Van Nederveen Meerkerk, 'Reconsidering The "FirstmaleBreadwinner Economy"'; Schmidt, 'Women and Guilds'; Humphries and Sarasúa, 'Off the Record'. 
labour was high and accordingly guilds were less restrictive towards women. ${ }^{67}$ Due to a combination of demographic and socio-economic changes, Dutch women's labour participation sharply declined in the nineteenth century. ${ }^{68}$ Although it is likely that the high level of women in the Dutch labour market before c. 1850 was related to their independent position and their greater legal autonomy, it is much less clear if a link exists between women's declining labour participation and the decline in women's participation in crime at the end of the nineteenth century. ${ }^{69}$

The level of male and female labour participation is a central issue in the debate about public roles and the rise of separate and private public spheres in the industrial period. In his pioneering work on the vanishing female, Feeley argues that industrialisation led to the emergence of separate private and public spheres and the exclusion of women from the labour market. As a result, women's public roles decreased, and so did their criminal activities. In addition, household ideologies are believed to have led to more lenient treatment of women by prosecutors and courts. ${ }^{70}$

Scholars agree that around 1800 the breadwinner ideology intensified among the middle classes, though there are doubts about the practical effects of changed household ideologies. Clark argues that self-sufficiency of both men and women remained necessary until at least the second half of the nineteenth century. ${ }^{71}$ The breadwinner ideology may apply to middle-class married women, while single women, widows and working-class married women remained very active in the public sphere. Both men and women contributed to the family income through activities inside as well as outside the home, and women's activities were much less restricted than is often assumed. ${ }^{72}$ Van der Heijden and Schmidt found that well into the nineteenth century women represented a considerable proportion of the public service employees in the towns of Holland. ${ }^{73}$ Moreover,

67 Schmidt, 'Women and Guilds', 185.

68 Schmidt and Van Nederveen Meerkerk, 'Reconsidering The "FirstmaleBreadwinner Economy"', 79-90.

69 Schmidt, 'Women and Guilds', 171.

70 Feeley and Little, 'The Vanishing Female'; Feeley, 'The Decline of Women in the Criminal Process'; Zedner, Women, Crime, and Custody; King, Crime and the Law, 194-5.

71 Clark, European Cities and Towns.

72 Schmidt and Van Nederveen Meerkerk, 'Reconsidering the "First Male-Breadwinner Economy"', 85-9.

73 Van der Heijden and Schmidt, 'Public Services and Women's Work'. 
there was no decline in the participation of women in public service in the course of the nineteenth century. ${ }^{74}$

Finally, the link between the breadwinner ideology and the trend in male and female crime is not clear. It remains uncertain whether an overall decline in the female portion in recorded crime occurred during the eighteenth and nineteenth centuries. Recent studies on Amsterdam, Freiburg and the southern area of Germany indicate otherwise. In the course of the eighteenth and nineteenth centuries, there was an increase rather than a decrease in women's share in crime. ${ }^{75}$ In southern Germany around 1800, 40 per cent of those arrested were women. The majority of the women prosecuted were lower-class unmarried and widowed women with employment outside the house. ${ }^{76}$ Between 1811 and 1835, 62 per cent of the female delinquents in Amsterdam had an occupation at the time of their arrest. Furthermore, the women of Amsterdam were increasingly accused of violence against neighbours. ${ }^{77}$ These figures indicate that dominant household ideologies did not necessarily represent men's and women's public activities.

\section{Rising Living Standards and Welfare Arrangements}

The paragraphs above showed that in the period between 1600 and 1850 women's agency and their proportion in crime was for a large part determined by three factors: norms regarding men's and women's behaviour, the level of urbanisation and the family system. The level of female labour participation may have been an important indicator for women's leeway to lead public and criminal lives, but it is not the dominant factor in the explanation for women's declining presence (in terms of both numbers and relativity to male prosecutions) in European courts from the last decades of the nineteenth century. Although systematic research on women's crimes in the transitional period between 1850 and 1920 needs to be done, there are indications that the low proportion of women in crime in Europe after 1850 were related to the improvement of living standards and the emergence of the welfare state. ${ }^{78}$

74 De Vries, The Industrious Revolution.

75 Ruitenbeek, 'Hem - de waereld, haar - het huis'?'; Wettmann-Jungblut, 'Modern Times, Modern Crimes?'.

76 Ibid., 174.

77 Ruitenbeek, 'Hem - de waereld, haar - het huis'?', 78-9; Ruitenbeek, 'Niet zonder kleerscheuren', 67-8.

78 Van Drenth and De Haan, The Rise of Caring Power. 
Economic historian Clark argues that the Industrial Revolution improved women's position. Though women faced more barriers to promotion than men, Clark insists that the relative wage was already an improvement over the situation in the pre-industrial period. He concludes that overall the equality between men and women in societies after 1850 increased rather than decreased. Besides material income, there were also improvements in the quality of life in terms of life expectancy, health, numbers of surviving children, literacy and consumption. ${ }^{79}$ De Vries recently added to the living standard debate the importance of consumer aspiration that would have encouraged families to revise family labour participation. By withdrawing the labour time of women from the market and redeploying it as household labour, families were able to produce domestic comfort, better nutrition and health. De Vries emphasises that new household divisions were the result of joint decisions by couples to improve health and comfort, not the outcome of renewed patriarchy. Moreover, he stresses that this labour division has existed only since 1900. Before that time, families acquired consumption objectives by putting all family members into the labour force ${ }^{80}$ It may be that after 1850 rising income and improving health care and social security made it less necessary for women to become involved in crime.

The economy was not the only factor that led to a general improvement of living standards after the second half of the nineteenth century. The emergence of the welfare state did so as well. In the early modern period, poor relief and health care had been organised and financed locally by a myriad of private initiatives and ecclesiastical and secular institutions, and this system was insufficient as well as exclusive. ${ }^{81}$ In the decades around 1900, the central state began to take on direct responsibility for the well-being of its citizens, and the emergence of this welfare state was accompanied with a growing supply of social care arrangements everywhere in Western Europe. Governments set up welfare programs to prevent families from falling in to abject poverty, and their attention was increasingly aimed at those who needed help the most: women and children. ${ }^{82}$ In their work on the welfare state in Europe between 1870 and 1933, German historians Althammer, Gestrich and Gründler rightly

\footnotetext{
79 Clark, European Cities and Towns, 272-83; De Vries, The Industrious Revolution, 199-210.

80 De Vries, The Industrious Revolution, 199, 210.

81 Van der Heijden, Civic Duty; Clark, European Cities and Towns.

82 Althammer, Gestrich and Gründler (eds.), The Welfare State and the 'Deviant Poor'.
} 
pointed to the downside of this development, but scholars generally agree that on the whole welfare policies did improve the lives of poor families. ${ }^{83}$

Rising living standards and new welfare arrangements were particularly important to women, whose crimes - more so than crimes committed by men - seem to have been related to poverty and low standard of living. German studies have shown that the increase in convictions of women in the second half of the eighteenth century was related to subsistence crises, causing a lack of resources for many families and forcing women to commit theft. The evidence points to a clear link between the types of offences committed by women and their poor living circumstances. Most of the women convicted in Germany in the late eighteenth and nineteenth century were unmarried, had no children, were not integrated in the urban social structures and came from poor lower-class families. For these women, theft was a survival strategy to maintain them when common resources were running out. Increasing poverty and mounting problems of vagrancy resulted not only in an increase of the actual committed crime, but also in harsher prosecution policies, which focused on the lower strata and outsiders who were not yet integrated in society. ${ }^{84}$

Assuming that poverty in the early modern period caused women to commit theft, improving living standards may explain very low female crime rates in Europe after 1900. Firstly, improvement and extension of welfare arrangements provided women much more survival opportunities that resulted in a real decrease in women's crimes. Althammer suggests that the proportion of women in court cases regarding begging and vagrancy declined in Europe in the course of the nineteenth century, because welfare provisions made them less dependent on almsgiving. ${ }^{85}$ Van Drenth and De Haan introduced the helpful term 'caring power', referring to women's increasing charitable activities such as caring for poor, disabled and convicted women. Those women also started support programmes for imprisoned women, which may have reduced female recidivism. ${ }^{86}$ Secondly, many poor and destitute women, who had traditionally come before the courts, increasingly ended up in new institutions such as workhouses, reform houses or other establishments for the poor. Weevers and Bijleveld found that in the late nineteenth-century Netherlands

83 Ibid.

84 Ibid.; Wettmann-Jungblut, 'Modern Times, Modern Crimes?', 139; Eibach, Frankfurter Verhöre, 293-327.

85 Althammer, 'Roaming Men, Sedentary Women?', 750.

86 Van Drenth and De Haan, Caring Power; Knepper, Writing the History of Crime, 173201,182 . 
the majority of women convicted of begging and vagrancy then sent to Dutch workhouses (Rijkswerkinrichtingen) were very poor, old and ill or disabled. ${ }^{87}$

Further research on prison records, workhouses and reform institutions is needed to draw definitive conclusions about the pattern of female prisoners, but it is plausible that improving living standards caused a decline in the share of women in recorded crime after 1870. Improvements in the quality of living, in terms of material income, life expectancy, health, numbers of surviving children, consumption and social care, had a positive impact on the lives of women in particular. The small numbers of women - as compared to men - who were confined in workhouses were predominantly old, single and isolated women. These women were not bad but exceptionally poor.

\section{Conclusion: A Model of Determinants}

The above sections discussed explanations for variation in female crime between 1600 and 1900 can be summarised in a model of determinants (see Table 2.1). This model proposes that the share of men and women in crime between 1600 and 1900 should be viewed as dynamic. Crime rates change and vary according to historical circumstances, which determine the public roles of men and women. The model assumes that the scope of men and women who undertake public activities had a defining influence on the gender differences in crime. In addition, the model tests how moral and legal norms, urbanisation, family system, labour participation and living standards can explain the radius of men's and women's public activities and thus their contribution to crime.

On the basis of the above model of determinants, this chapter offers some preliminary conclusions on the variation in crime rates in relation to gender. First of all, there seem to have been crucial differences between the early modern period (1600-1850) and the period after c. 1850 . Due to a combination of factors, women's proportion in crime was much higher in the period between 1600 and 1800; in some European regions even as high as 50 per cent. Legal and moral norms regarding sexual behaviour and double standards certainly contributed to higher prosecution rates of women, but women's agency and their leeway to lead public lives played an important role as well. Firstly, the level of urbanisation was an important factor in the degree of women's

87 Weevers and Bijleveld, 'Utgediende hetaeren, verjaagde concubines en in de steek gelatenen', Weevers and Bijleveld, 'Thans zal met kracht het breien van kousen worden voortgezet'. 
Table 2.1. Determinants of public roles and the effect on crime rates of men and women, $1600-1900$

\begin{tabular}{|c|c|c|}
\hline Determinants & Effect on public roles & Effect on crime rates \\
\hline $\begin{array}{l}\text { Moral and legal norms } \\
\text { of public roles }\end{array}$ & $\begin{array}{l}\text { Men lead more public lives } \\
\text { than women }\end{array}$ & $\begin{array}{l}\text { Biased criminal procedures: } \\
\text { 1. Men commit more crimes } \\
\text { than women. } \\
\text { 2. Men more often prosecuted. } \\
\text { 3. Men and women prosecuted } \\
\text { for specific types of crime. }\end{array}$ \\
\hline Level of urbanisation & $\begin{array}{l}\text { Higher: >larger public roles } \\
\text { Lower: <lesser public roles }\end{array}$ & $\begin{array}{l}>\text { Higher female shares of crime } \\
<\text { Lower female shares of crime }\end{array}$ \\
\hline $\begin{array}{l}\text { Gender equality in } \\
\text { family system }\end{array}$ & $\begin{array}{l}\text { Higher: >larger public roles } \\
\text { Lower: <lesser public roles }\end{array}$ & $\begin{array}{l}>\text { Higher female shares of crime } \\
<\text { Lower female shares of crime }\end{array}$ \\
\hline $\begin{array}{l}\text { Gender equality in } \\
\text { labour participation }\end{array}$ & $\begin{array}{l}\text { Higher: >larger public roles } \\
\text { Lower: < lesser public roles }\end{array}$ & $\begin{array}{l}>\text { Higher female shares of crime } \\
<\text { Lower female shares of crime }\end{array}$ \\
\hline $\begin{array}{l}\text { Living standards/welfare } \\
\text { arrangements }\end{array}$ & $\begin{array}{l}\text { Lower: >larger public roles } \\
\text { Higher: < lower public roles }\end{array}$ & $\begin{array}{l}>\text { Higher female shares of crime } \\
<\text { Lower female shares of crime }\end{array}$ \\
\hline
\end{tabular}

public roles: due to their independent and risky lives, women's share in recorded crime was considerably higher in towns and cities than in the countryside. Secondly, the proportion of women in crime was higher in regions with greater gender equality in the family system and higher female labour participation rates, such as in England and Holland. In regions characterised by less gender equality in the family system and/ or labour participation, women's public lives were much more limited, and so was their contribution to crime.

The tables turned at the end of the nineteenth century when women's appearance in the criminal process declined everywhere throughout Western Europe. Feeley suggests that women's removal from the labour market and their confinement to the household was related to industrialisation and patriarchal values, but there is no clear correlation between the process of industrialisation and the declining proportion of women in crime. Rising living standards and the emergence of the welfare state in Europe seem to offer a more plausible explanation for women's declining contribution to crime. Improving economic and social conditions may have made it less necessary for women to lead risky and criminal lives, and if they did, women and children were more likely to receive support through welfare arrangements. Those women who did come in contact with the law and were sentenced to prisons and workhouses seem to belong to a rather exceptionally small and poor group of women. 
In sum, a long-term and comparative perspective demonstrates that women's proportion in crime is not static but varies across time and space. The variation in crime and gender can be explained by a combination of legal and socio-economic factors, such as the norms regarding women's behaviour, the level of urbanisation, the degree of gender equality and the degree of living standards and welfare arrangements. Finally, there are crucial differences between the period before c. 1870 and after. More research on men's and women's crimes in the transitional period between 1850 and 1920 is needed to come to decisive conclusions about the impact of the welfare state on the decline of women in the criminal process. 
Downloaded from https://www.cambridge.org/core. Walaeus Library LUMC, on 10 Nov 2021 at 09:57:10, subject to the Cambridge Core terms of use, available at https://www.cambridge.org/core/terms. https://doi.org/10.1017/9781108774543.002 